Viewpoint

\title{
CCR5 Promoter Polymorphism -2459G > A: Forgotten or Ignored?
}

\author{
Rajeev K. Mehlotra \\ Center for Global Health and Diseases, Case Western Reserve University School of Medicine, \\ Cleveland, OH 44106, USA; rkm@case.edu; Tel.: +1-216-368-6172; Fax: +1-216-368-4825
}

Received: 30 May 2019; Accepted: 27 June 2019; Published: 28 June 2019

\begin{abstract}
C-C chemokine receptor 5 (CCR5) polymorphisms, particularly a 32-base pair deletion $(\Delta 32)$ in the open reading frame and $-2459 \mathrm{G}>\mathrm{A}$ in the promoter, are well known for their associations with HIV-1 infection and/or disease progression in a variety of studies. In this era of an HIV cure, where all the emphasis is on $\Delta 32$, it seems that $-2459 \mathrm{G}>\mathrm{A}$ has been forgotten or ignored. There is significant importance in the incorporation of the CCR5-2459G > A genotype information into studies evaluating new immunologic and chemotherapeutic strategies, and those designing and implementing better treatment strategies with current antiretroviral therapy, doing so would enable a better understanding of the response to the intervention, due to a mechanistic or constitutive explanation. Until we find a strategy, whether a stem-cell transplantation or CCR5 editing approach or something else, that delivers a cure to the millions, we should make use of every piece of information that may help curtail HIV/AIDS as a threat to public health.
\end{abstract}

Keywords: CCR5; Delta32; haplotype; HIV cure; host genetics; promoter polymorphism; -2459G > A

A variety of studies conducted in the 1990s examined the associations between C-C chemokine receptor 5 (CCR5) polymorphisms (a 32-base pair deletion $[\Delta 32, \mathrm{rs} 333]$ in the open reading frame [ORF] and a single nucleotide polymorphism [SNP] -2459G $>$ A [also known as 59029G $>$ A and 303G $>A$, rs1799987] in the promoter) and HIV-1 infection and disease progression. In those studies, the $\Delta 32$ allele, compared with the wild-type (wt) allele, was associated with protection against HIV infection and/or delayed disease progression [1-3]. The $-2459 \mathrm{G}$ allele, compared with the $-2459 \mathrm{~A}$ allele, was associated with delayed HIV disease progression [2,4].

In a number of studies, the $\Delta 32$ and $-2459 \mathrm{G}$ alleles were associated with significantly reduced in vitro promoter activity, CCR5 expression, and HIV propagation, compared with the ORF wt and -2459 A alleles, respectively [4-9]. Shieh et al. [9] found that individuals homozygous for the -2459 A/A genotype had significantly increased number of CD4+ T cells expressing CCR5. Through in vitro infection of peripheral blood mononuclear cells, which were isolated from healthy donors, with a CCR5-tropic HIV isolate, Salkowitz et al. [8] showed that -2459G > A was associated with CCR5 expression as well as the magnitude of HIV-1 propagation: low, medium, and high levels of viral propagation were associated with G/G, G/A, and A/A promoter genotypes, respectively. Further flow cytometric analysis of unstimulated CD14+ monocytes from the same donors revealed that a similar hierarchy of CCR5 receptor density was associated with the same promoter genotypes. In another study involving healthy individuals, CCR5-tropic HIV infection levels in Langerhans cells (LCs) ex vivo were also associated with the CCR5 genotype [6]: LCs isolated from individuals, who were genotypically $-2459 \mathrm{G} / \mathrm{A}$ and ORF $\mathrm{wt} / \Delta 32$, were markedly less susceptible to HIV than LCs from individuals who were genotypically $-2459 \mathrm{~A} / \mathrm{A}$ and ORF wt/ $\Delta 32$.

Recent studies have advanced our understanding regarding the relationship between these polymorphisms and transcriptional regulation of the CCR5 promoter, and how this relationship affects 
CCR5 cell surface expression vis-à-vis disease phenotype [10,11]. In addition, they suggest a possible role of these polymorphisms in HIV pathogenesis, where the promoter activity may regulate bystander CD4+ T cell apoptosis and loss [11,12].

The abovementioned findings provide a biological explanation that enables us to better understand certain genetic aspects of host factors associated with susceptibility to HIV-1 infection, propagation, and progression to AIDS. They also parallel the results of genetic susceptibility studies performed in large cohorts of HIV-infected individuals, which showed that the CCR5 $\triangle 32$ and -2459G alleles were associated with protection against HIV infection and/or delayed disease progression, compared with the ORF wt and -2459A alleles, respectively [1-4].

According to a recent multipopulation study, donors from Norway had the highest allele frequency of CCR5 $\Delta 32(16.41 \%)$, followed by those from the two Baltic states Estonia (15.63\%) and Latvia $(15.09 \%)$. The lowest allele frequency of CCR5 $\triangle 32$ was observed in donors from Eritrea $(0.26 \%)$ and from Ethiopia $(0 \%, n=76)$ [13]. Donors from the Faroe Islands, Belarus, and Finland had the highest genotype frequencies of CCR5 $\Delta 32 / \Delta 32(2.33 \%, 2.19 \%$, and $2.04 \%$, respectively) within this data set [13]. On the other hand, in most populations, allele frequency of CCR5 -2459A ranges from 29\% to 59\% [14-17]. In Papua New Guinea (PNG), an Oceania country, this allele frequency was much higher, $85 \%$ in one study [14] and $98 \%$ in another [17].

The CCR5 haplotype nomenclature system consists of a total of nine polymorphisms, which include CCR5 ORF wt/ $\triangle 32$ and -2459G > A [7,18]. The other seven polymorphisms are: one CCR2 ORF SNP 190G > A (Val64Ile), rs1799864; and six CCR5 promoter SNPs -2773A > G (rs2856758), $-2554 \mathrm{G}>\mathrm{T}(\mathrm{rs} 2734648),-2135 \mathrm{~T}>\mathrm{C}(\mathrm{rs} 1799988),-2132 \mathrm{C}>\mathrm{T}(\mathrm{rs} 41469351),-2086 \mathrm{~A}>\mathrm{G}(\mathrm{rs} 1800023)$, and $-1835 C>T$ (rs1800024). Using these nine CCR2-CCR5 polymorphisms, haplotypes have been organized into seven evolutionarily distinct human haplogroups $(\mathrm{HH})$ designated HHA, $-\mathrm{B},-\mathrm{C},-\mathrm{D},-\mathrm{E}$, $-F\left(F^{*} 1\right.$ and $\left.F^{*} 2\right)$, and $-G\left(G^{*} 1\right.$ and $\left.G^{*} 2\right)$ (Table 1$)$.

Table 1. CCR5 haplotype nomenclature ${ }^{\dagger}$.

\begin{tabular}{|c|c|c|c|c|c|c|c|c|c|}
\hline Haplotype & $\begin{array}{c}\text { CCR2 } \\
190\end{array}$ & $\begin{array}{l}\text { CCR5 } \\
-2733\end{array}$ & $\begin{array}{l}\text { CCR5 } \\
-2554\end{array}$ & $\begin{array}{l}\text { CCR5 } \\
-2459\end{array}$ & $\begin{array}{l}\text { CCR5 } \\
-2135\end{array}$ & $\begin{array}{l}\text { CCR5 } \\
-2132\end{array}$ & $\begin{array}{l}\text { CCR5 } \\
-2086\end{array}$ & $\begin{array}{l}\text { CCR5 } \\
-1835\end{array}$ & $\begin{array}{c}\text { CCR5 } \\
\text { ORF }\end{array}$ \\
\hline HHA & G & A & G & G & $\mathrm{T}$ & C & A & C & wt \\
\hline HHB & G & A & $\mathrm{T}$ & G & $\mathrm{T}$ & C & A & C & wt \\
\hline $\mathrm{HHC}$ & G & A & $\mathrm{T}$ & G & $\mathrm{T}$ & C & G & C & wt \\
\hline HHD & G & A & $\mathrm{T}$ & G & $\mathrm{T}$ & $\mathrm{T}$ & $\mathrm{A}$ & C & wt \\
\hline HHE & G & A & G & A & C & C & A & C & wt \\
\hline $\mathrm{HHF}^{*} 1$ & G & A & G & A & C & C & A & $\mathrm{T}$ & wt \\
\hline $\mathrm{HHF}^{*} 2$ & A & A & G & A & C & C & A & $\mathrm{T}$ & wt \\
\hline $\mathrm{HHG}^{*} 1$ & G & G & G & A & C & $\mathrm{C}$ & A & C & wt \\
\hline $\mathrm{HHG}^{*} 2$ & G & G & G & A & $\mathrm{C}$ & C & A & C & $\Delta 32$ \\
\hline
\end{tabular}

Among these haplotypes, -2459G allele-carrying HHA (frequency range 6-71\%) and HHC (frequency range $2-42 \%$ ), and $-2459 \mathrm{~A}$ allele-carrying HHE (frequency range $12-37 \%$ ) and $\mathrm{HHF}^{* 2}$ (frequency range $5-24 \%$ ) are highly prevalent $[15,17,18]$. In PNG, the frequency of HHE was $92 \%$, and therefore $84 \%$ individuals were homozygous for this haplotype [17].

In the same way that the ORF wt/ $\Delta 32$ and $-2459 \mathrm{G} / \mathrm{A}$ alleles show differences in phenotypic effects in vitro as well as in HIV/AIDS cohorts, different CCR5 haplotypes influence HIV infection and disease outcomes differently [18-23]. Among CCR5 haplotypes (HHA-HHG*2), the consistency of the association of HHE homozygosity (E/E diplotype) with an unfavorable outcome across diverse populations is noteworthy: This diplotype was significantly associated with disease acceleration, particularly an accelerated progression to death in Caucasians [18]. It was also significantly associated with HIV-1 seroconversion, higher early HIV-1 RNA levels, and a shorter time to AIDS in diverse North American cohorts [21,22]. Association between HHE and rapid HIV-1 disease progression was also observed in patients from Rwanda [24], Spain [25], and Thailand [26]. Even in children from Argentina, there was a strong association between the $\mathrm{E} / \mathrm{E}$ diplotype and susceptibility to perinatal transmission 
of HIV-1, accelerated rate of progression to AIDS, and a more rapid progression to death [20]. A recent study investigating the association between CCR5 haplotypes and HIV tropism in Estonian Caucasians found that HHE was associated with the presence of C-X-C chemokine receptor 4-tropic viruses [19]. Unfavorable outcomes, ranging from seroconversion to disease progression, associated with $\mathrm{HHE}$ have also been reported in other recent studies [27-29]. These consistent findings suggest that the HHE haplotype confers similar phenotypic effects against distinct genetic backgrounds.

$\mathrm{HHF}^{* 2}$ is the other highly prevalent -2459A allele-carrying haplotype, and is the only haplotype that carries the CCR2 ORF 190A (64Ile) allele (Table 1). Consistent with the results revealing that the 190A allele was associated with protection against HIV infection and/or delayed disease progression, the $\mathrm{HHF}^{*} 2$ haplotype was found to be protective in various cohort studies $[18,20,21]$. However, its effects as $\mathrm{HHF}^{*} 2 / \mathrm{HHE}$ diplotype are unclear [20,21].

Given this background, the question is, has $-2459 \mathrm{G}>\mathrm{A}$ been forgotten or ignored in this era of an HIV cure, where all the emphasis is on $\Delta 32$ ? In this regard, I present some examples from the literature, together with my limited personal experiences, which suggest that it may have been. This may be because, recently, we have started to recognize that the effect of host genetic variation in HIV/AIDS is a complex phenomenon [30], and investigating strategies that may close the door to HIV-1 may have a really meaningful effect. So far, an HIV cure has been achieved for two patients, the "Berlin patient" and the "London patient". A third patient, the "Düsseldorf patient", may be on the way to being cured. These HIV patients received allogenic hematopoietic stem-cell transplants from CCR5 $\Delta 32 / \Delta 32$ donors for their life-threatening blood cancers. Because CCR5 $\Delta 32 / \Delta 32$ donors are rare [13], and such transplants come with significant risks, this approach may not be an option yet to treat people with HIV worldwide. But the fact that the approach seems to work could point the way to other strategies for a cure. One possibility might be to edit CCR5 to engineer cells resistant to HIV-1 infection [31,32]. Whether a stem-cell transplantation or CCR5 editing approach is taken, considering the $-2459 \mathrm{G}>\mathrm{A}$ status is, obviously, irrelevant.

However, considering the $-2459 \mathrm{G}>\mathrm{A}$ status may be important in studies where (a) immunologic strategies, such as antibodies for CCR5 [33], HIV-1 neutralizing antibodies [34,35], and therapeutic HIV-1 vaccines [36], and (b) chemotherapeutic strategies, such as CCR5 antagonists [37-39], are evaluated. Here, knowing whether an individual, receiving such an immunologic or chemotherapeutic intervention, is genotypically $\mathrm{G} / \mathrm{G}, \mathrm{G} / \mathrm{A}$, or $\mathrm{A} / \mathrm{A}$ would enable a better understanding of the response to the intervention, due to a mechanistic or constitutive explanation. Whether the -2459 genotype information was generated and included in such studies is an open question; to the best of my knowledge, the answer is No. This is based on literature search using PubMed (https://www.ncbi.nlm. nih.gov/pubmed/) and personal communication/interaction with scientists regarding their work on HIV-1 neutralizing antibodies [34,35] and the antiviral activity of aprepitant (a neurokinin 1 receptor antagonist that down-regulates the expression of CCR5) $[40,41]$.

Finally, among the HIV/AIDS treatment studies conducted 10-20 years ago, some showed that the CCR5 $\triangle 32$ and $-2459 \mathrm{G}$ alleles were associated with improved clinical outcomes in highly active antiretroviral therapy (HAART)-treated patients. This finding was consistent with observations in treatment-naive patients. On the other hand, some studies reported an insignificant trend or no effect of these polymorphisms on response to HAART (see [16] for all references). In a North American, HIV-positive, HAART-treated, adherent cohort of self-identified white (Caucasian) and black (African American) patients, who were followed for $\geq 6$ months after initiation of HAART, we observed that $-2459 \mathrm{G}>$ A genotype had a strong association with time to achieve virologic success (TVLS) in black but not in white patients [16]. Among black patients, those who carried the $-2459 \mathrm{G}$ allele achieved virologic success significantly earlier. We could not compare our findings directly with the findings of previous studies (referenced in [16]) because those studies were conducted in various populations under a variety of designs. In addition, the race-specific influence of the $-2459 \mathrm{G}$ allele, observed in black patients in our study, was not reported in any of those studies. More recently, in a follow-up study, we observed that the race-specific association between -2459G > A genotype and TVLS of HAART 
increased with stronger African ancestry [42]. Further genetic and genomic analyses (e.g., genetic variation in and around the CCR5 locus, multilocus genetic interactions, etc.) are needed in order to elucidate the possible mechanisms underlying this race-specific association.

Thus, in my view, incorporating the CCR $5-2459 \mathrm{G}>$ A genotype information into studies evaluating new immunologic and chemotherapeutic strategies is important. In addition, studies designing and implementing better treatment strategies with current HAART should also include this information. Given the significance of $\Delta 32$, even when present as a single allele, the ORF $w t / \Delta 32$ genotype information ought to be included in such studies. If it is included, then why not the information related to CCR $5-2459 \mathrm{G}>$ A genotype, if not the entire haplotype? Until we find a strategy that delivers a cure to the millions, we should make use of every piece of information that may help curtail HIV/AIDS as a threat to public health.

Funding: This work was supported by a Development Award from the Center for AIDS Research, University Hospitals Case Medical Center, Cleveland, OH, U.S.A. (NIH grant \#AI36219) and a Large Pilot Grant from the Case Western Reserve University/Cleveland Clinic CTSA grant \#UL1RR024989 (National Center for Research Resources, NIH).

Acknowledgments: I dedicate this article to Peter Zimmerman, who has deeply inspired me through his well-recognized work on chemokine receptor-ligand genetic associations in HIV/AIDS. I would like to acknowledge the contributions of Riley Tedrow and Carolyn Myers, who have read the manuscript and made valuable suggestions and criticisms. Without such help, this article would not have been as successful.

Conflicts of Interest: The author declares no conflict of interest.

\section{References}

1. Dean, M.; Carrington, M.; Winkler, C.; Huttley, G.A.; Smith, M.W.; Allikmets, R.; Goedert, J.J.; Buchbinder, S.P.; Vittinghoff, E.; Gomperts, E.; et al. Genetic restriction of HIV-1 infection and progression to AIDS by a deletion allele of the CKR5 structural gene. Hemophilia Growth and Development Study, Multicenter AIDS Cohort Study, Multicenter Hemophilia Cohort Study, San Francisco City Cohort, ALIVE Study. Science 1996, 273, 1856-1862. [PubMed]

2. Martin, M.P.; Dean, M.; Smith, M.W.; Winkler, C.; Gerrard, B.; Michael, N.L.; Lee, B.; Doms, R.W.; Margolick, J.; Buchbinder, S.; et al. Genetic acceleration of AIDS progression by a promoter variant of CCR5. Science 1998, 282, 1907-1911. [CrossRef] [PubMed]

3. Zimmerman, P.A.; Buckler-White, A.; Alkhatib, G.; Spalding, T.; Kubofcik, J.; Combadiere, C.; Weissman, D.; Cohen, O.; Rubbert, A.; Lam, G.; et al. Inherited resistance to HIV-1 conferred by an inactivating mutation in CC chemokine receptor 5: Studies in populations with contrasting clinical phenotypes, defined racial background, and quantified risk. Mol. Med. 1997, 3, 23-36. [CrossRef] [PubMed]

4. McDermott, D.H.; Zimmerman, P.A.; Guignard, F.; Kleeberger, C.A.; Leitman, S.F.; Murphy, P.M. CCR5 promoter polymorphism and HIV-1 disease progression. Multicenter AIDS Cohort Study (MACS). Lancet 1998, 352, 866-870. [CrossRef]

5. Hladik, F.; Liu, H.; Speelmon, E.; Livingston-Rosanoff, D.; Wilson, S.; Sakchalathorn, P.; Hwangbo, Y.; Greene, B.; Zhu, T.; McElrath, M.J. Combined effect of CCR5- $\triangle 32$ heterozygosity and the CCR5 promoter polymorphism $-2459 \mathrm{~A} / \mathrm{G}$ on CCR5 expression and resistance to human immunodeficiency virus type 1 transmission. J. Virol. 2005, 79, 11677-11684. [CrossRef] [PubMed]

6. Kawamura, T.; Gulden, F.O.; Sugaya, M.; McNamara, D.T.; Borris, D.L.; Lederman, M.M.; Orenstein, J.M.; Zimmerman, P.A.; Blauvelt, A. R5 HIV productively infects Langerhans cells, and infection levels are regulated by compound CCR5 polymorphisms. Proc. Natl. Acad. Sci. USA 2003, 100, 8401-8406. [CrossRef] [PubMed]

7. Mummidi, S.; Bamshad, M.; Ahuja, S.S.; Gonzalez, E.; Feuillet, P.M.; Begum, K.; Galvis, M.C.; Kostecki, V.; Valente, A.J.; Murthy, K.K.; et al. Evolution of human and non-human primate CC chemokine receptor 5 gene and mRNA. Potential roles for haplotype and mRNA diversity, differential haplotype-specific transcriptional activity, and altered transcription factor binding to polymorphic nucleotides in the pathogenesis of HIV-1 and simian immunodeficiency virus. J. Biol. Chem. 2000, 275, 18946-18961. 
8. Salkowitz, J.R.; Bruse, S.E.; Meyerson, H.; Valdez, H.; Mosier, D.E.; Harding, C.V.; Zimmerman, P.A.; Lederman, M.M. CCR5 promoter polymorphism determines macrophage CCR5 density and magnitude of HIV-1 propagation in vitro. Clin. Immunol. 2003, 108, 234-240. [CrossRef]

9. Shieh, B.; Liau, Y.E.; Hsieh, P.S.; Yan, Y.P.; Wang, S.T.; Li, C. Influence of nucleotide polymorphisms in the CCR2 gene and the CCR5 promoter on the expression of cell surface CCR5 and CXCR4. Int. Immunol. 2000, 12, 1311-1318. [CrossRef]

10. Gonzalo-Gil, E.; Rapuano, P.B.; Ikediobi, U.; Leibowitz, R.; Mehta, S.; Coskun, A.K.; Porterfield, J.Z.; Lampkin, T.D.; Marconi, V.C.; Rimland, D.; et al. Transcriptional down-regulation of ccr5 in a subset of HIV+ controllers and their family members. Elife 2019, 8. [CrossRef]

11. Joshi, A.; Punke, E.B.; Sedano, M.; Beauchamp, B.; Patel, R.; Hossenlopp, C.; Alozie, O.K.; Gupta, J.; Mukherjee, D.; Garg, H. CCR5 promoter activity correlates with HIV disease progression by regulating CCR5 cell surface expression and CD4 T cell apoptosis. Sci. Rep. 2017, 7, 232. [CrossRef] [PubMed]

12. Garg, H.; Joshi, A. Host and viral factors in HIV-mediated bystander apoptosis. Viruses 2017, 9, 237. [CrossRef] [PubMed]

13. Solloch, U.V.; Lang, K.; Lange, V.; Bohme, I.; Schmidt, A.H.; Sauter, J. Frequencies of gene variant CCR5-Delta32 in 87 countries based on next-generation sequencing of 1.3 million individuals sampled from 3 national DKMS donor centers. Hum. Immunol. 2017, 78, 710-717. [CrossRef] [PubMed]

14. Clark, V.J.; Dean, M. Haplotype structure and linkage disequilibrium in chemokine and chemokine receptor genes. Hum. Genomics 2004, 1, 255-273. [CrossRef] [PubMed]

15. Gonzalez, E.; Dhanda, R.; Bamshad, M.; Mummidi, S.; Geevarghese, R.; Catano, G.; Anderson, S.A.; Walter, E.A.; Stephan, K.T.; Hammer, M.F.; et al. Global survey of genetic variation in CCR5, RANTES, and MIP-1 $\alpha$ : Impact on the epidemiology of the HIV-1 pandemic. Proc. Natl. Acad. Sci. USA 2001, 98, 5199-5204. [CrossRef] [PubMed]

16. Mehlotra, R.K.; Cheruvu, V.K.; Blood Zikursh, M.J.; Benish, R.L.; Lederman, M.M.; Salata, R.A.; Gripshover, B.; McComsey, G.A.; Lisgaris, M.V.; Fulton, S.; et al. Chemokine (C-C motif) receptor 5 -2459 genotype in patients receiving highly active antiretroviral therapy: Race-specific influence on virologic success. J. Infect. Dis. 2011, 204, 291-298. [CrossRef] [PubMed]

17. Mehlotra, R.K.; Hall, N.B.; Bruse, S.E.; John, B.; Zikursh, M.J.B.; Stein, C.M.; Siba, P.M.; Zimmerman, P.A. CCR2, CCR5, and CXCL12 variation and HIV/AIDS in Papua New Guinea. Infect. Genet. Evol. 2015, 36, 165-173. [CrossRef] [PubMed]

18. Gonzalez, E.; Bamshad, M.; Sato, N.; Mummidi, S.; Dhanda, R.; Catano, G.; Cabrera, S.; McBride, M.; Cao, X.H.; Merrill, G.; et al. Race-specific HIV-1 disease-modifying effects associated with CCR5 haplotypes. Proc. Natl. Acad. Sci. USA 1999, 96, 12004-12009. [CrossRef]

19. Huik, K.; Avi, R.; Uibopuu, H.; Pauskar, M.; Margus, T.; Karki, T.; Krispin, T.; Kool, P.; Ruutel, K.; Talu, A.; et al. Association Between HIV-1 Tropism and CCR5 Human Haplotype E in a Caucasian Population. J. Acquir. Immune Defic. Syndr. 2014, 66, 239-244. [CrossRef]

20. Mangano, A.; Gonzalez, E.; Dhanda, R.; Catano, G.; Bamshad, M.; Bock, A.; Duggirala, R.; Williams, K.; Mummidi, S.; Clark, R.A.; et al. Concordance between the CC chemokine receptor 5 genetic determinants that alter risks of transmission and disease progression in children exposed perinatally to human immunodeficiency virus. J. Infect. Dis. 2001, 183, 1574-1585. [CrossRef]

21. Tang, J.; Shelton, B.; Makhatadze, N.J.; Zhang, Y.; Schaen, M.; Louie, L.G.; Goedert, J.J.; Seaberg, E.C.; Margolick, J.B.; Mellors, J.; et al. Distribution of chemokine receptor CCR2 and CCR5 genotypes and their relative contribution to human immunodeficiency virus type 1 (HIV-1) seroconversion, early HIV-1 RNA concentration in plasma, and later disease progression. J. Virol. 2002, 76, 662-672. [CrossRef] [PubMed]

22. Tang, J.; Wilson, C.M.; Schaen, M.; Myracle, A.; Douglas, S.D.; Kaslow, R.A.; Group, R.S. CCR2 and CCR5 genotypes in HIV type 1-infected adolescents: Limited contributions to variability in plasma HIV type 1 RNA concentration in the absence of antiretroviral therapy. AIDS Res. Hum. Retroviruses 2002, 18, 403-412. [CrossRef] [PubMed]

23. Kostrikis, L.G.; Neumann, A.U.; Thomson, B.; Korber, B.T.; McHardy, P.; Karanicolas, R.; Deutsch, L.; Huang, Y.; Lew, J.F.; McIntosh, K.; et al. A polymorphism in the regulatory region of the CC-chemokine receptor 5 gene influences perinatal transmission of human immunodeficiency virus type 1 to African-American infants. J. Virol. 1999, 73, 10264-10271. [PubMed] 
24. Kaslow, R.A. Presented at 8th Conference on Retroviruses and Opportunistic Infections, Chicago, IL, USA, 2001; Abstract \#45B.

25. Li, M.; Song, R.; Masciotra, S.; Soriano, V.; Spira, T.J.; Lal, R.B.; Yang, C. Association of CCR5 human haplogroup E with rapid HIV type 1 disease progression. AIDS Res. Hum. Retroviruses 2005, 21, 111-115. [CrossRef] [PubMed]

26. Nguyen, L.; Li, M.; Chaowanachan, T.; Hu, D.J.; Vanichseni, S.; Mock, P.A.; van Griensven, F.; Martin, M.; Sangkum, U.; Choopanya, K.; et al. CCR5 promoter human haplogroups associated with HIV-1 disease progression in Thai injection drug users. AIDS 2004, 18, 1327-1333. [CrossRef]

27. Coloccini, R.S.; Dilernia, D.; Ghiglione, Y.; Turk, G.; Laufer, N.; Rubio, A.; Socias, M.E.; Figueroa, M.I.; Sued, O.; Cahn, P.; et al. Host genetic factors associated with symptomatic primary HIV infection and disease progression among Argentinean seroconverters. PLoS ONE 2014, 9, e113146. [CrossRef] [PubMed]

28. Jaumdally, S.Z.; Picton, A.; Tiemessen, C.T.; Paximadis, M.; Jaspan, H.B.; Gamieldien, H.; Masson, L.; Coetzee, D.; Williamson, A.L.; Little, F.; et al. CCR5 expression, haplotype and immune activation in protection from infection in HIV-exposed uninfected individuals in HIV-serodiscordant relationships. Immunology 2017, 151, 464-473. [CrossRef]

29. Malhotra, R.; Hu, L.; Song, W.; Brill, I.; Mulenga, J.; Allen, S.; Hunter, E.; Shrestha, S.; Tang, J.; Kaslow, R.A. Association of chemokine receptor gene (CCR2-CCR5) haplotypes with acquisition and control of HIV-1 infection in Zambians. Retrovirology 2011, 8, 22. [CrossRef]

30. Mehlotra, R.K. Human genetic variation and HIV/AIDS in Papua New Guinea: Time to connect the dots. Curr. HIV/AIDS Rep. 2018, 15, 431-440. [CrossRef]

31. Allen, A.G.; Chung, C.H.; Atkins, A.; Dampier, W.; Khalili, K.; Nonnemacher, M.R.; Wigdahl, B. Gene editing of HIV-1 co-receptors to prevent and/or cure virus infection. Front. Microbiol. 2018, 9, 2940. [CrossRef]

32. Kou, J.; Kuang, Y.Q. Mutations in chemokine receptors and AIDS. Prog. Mol. Biol. Transl. Sci. 2019, 161, 113-124. [PubMed]

33. Prathipati, P.K.; Mandal, S.; Destache, C.J. A review of CCR5 antibodies against HIV: Current and future aspects. Ther. Deliv. 2019, 10, 107-112. [CrossRef] [PubMed]

34. Bar-On, Y.; Gruell, H.; Schoofs, T.; Pai, J.A.; Nogueira, L.; Butler, A.L.; Millard, K.; Lehmann, C.; Suarez, I.; Oliveira, T.Y.; et al. Safety and antiviral activity of combination HIV-1 broadly neutralizing antibodies in viremic individuals. Nat. Med. 2018, 24, 1701-1707. [CrossRef] [PubMed]

35. Mendoza, P.; Gruell, H.; Nogueira, L.; Pai, J.A.; Butler, A.L.; Millard, K.; Lehmann, C.; Suarez, I.; Oliveira, T.Y.; Lorenzi, J.C.C.; et al. Combination therapy with anti-HIV-1 antibodies maintains viral suppression. Nature 2018, 561, 479-484. [CrossRef] [PubMed]

36. Jacobson, J.M.; Khalili, K. Toward the cure of HIV-1 infection: Lessons learned and yet to be learned as new strategies are developed. AIDS Rev. 2018, 20, 220-225. [CrossRef] [PubMed]

37. Grande, F.; Occhiuzzi, M.A.; Rizzuti, B.; Ioele, G.; De Luca, M.; Tucci, P.; Svicher, V.; Aquaro, S.; Garofalo, A. CCR5/CXCR4 dual antagonism for the improvement of HIV infection therapy. Molecules 2019, 24. [CrossRef]

38. Mostashari Rad, T.; Saghaie, L.; Fassihi, A. HIV-1 entry inhibitors: A review of experimental and computational studies. Chem. Biodivers. 2018, 15, e1800159. [CrossRef]

39. Tian, Y.; Zhang, D.; Zhan, P.; Liu, X. Medicinal chemistry of small molecule CCR5 antagonists for blocking HIV-1 entry: A review of structural evolution. Curr. Top. Med. Chem. 2014, 14, 1515-1538. [CrossRef] [PubMed]

40. Manak, M.M.; Moshkoff, D.A.; Nguyen, L.T.; Meshki, J.; Tebas, P.; Tuluc, F.; Douglas, S.D. Anti-HIV-1 activity of the neurokinin-1 receptor antagonist aprepitant and synergistic interactions with other antiretrovirals. AIDS 2010, 24, 2789-2796. [CrossRef]

41. Tebas, P.; Tuluc, F.; Barrett, J.S.; Wagner, W.; Kim, D.; Zhao, H.; Gonin, R.; Korelitz, J.; Douglas, S.D. A randomized, placebo controlled, double masked phase IB study evaluating the safety and antiviral activity of aprepitant, a neurokinin-1 receptor antagonist in HIV-1 infected adults. PLoS ONE 2011, 6, e24180. [CrossRef]

42. Cheruvu, V.K.; Igo, R.P., Jr.; Jurevic, R.J.; Serre, D.; Zimmerman, P.A.; Rodriguez, B.; Mehlotra, R.K. African ancestry influences CCR5 -2459G >A genotype-associated virologic success of highly active antiretroviral therapy. J. Acquir. Immune Defic. Syndr. 2014, 66, 102-107. [CrossRef] [PubMed]

(C) 2019 by the author. Licensee MDPI, Basel, Switzerland. This article is an open access article distributed under the terms and conditions of the Creative Commons Attribution (CC BY) license (http://creativecommons.org/licenses/by/4.0/). 